\title{
Static and Dynamic Evaluations of College Teaching Quality
}

\author{
https://doi.org/10.3991/ijet.v17i02.29005 \\ Jianli Liu( $\left.{ }^{\bowtie}\right)$, Yuan Wang \\ Shijiazhuang University of Applied Technology, Shijiazhuang, China \\ liujlesjzpt.edu.cn
}

\begin{abstract}
Taking economic management majors as an example, this paper probes deep into the teaching quality evaluation of colleges. Questionnaire survey was combined with interviews to survey the teachers and students of economic management majors in 10 colleges of a Chinese province. The current state and influencing factors of teaching quality evaluation were analyzed based on the survey data. The problems and defects were summarized for the teaching quality evaluation of economic management majors. On this basis, an evaluation index system was established for college teaching quality, drawing on both static and dynamic evaluations. The weight of each index was determined through expert scoring. Then, an empirical study was carried out on the teaching quality evaluation of the economic management major in a Chinese college. The results show that the proposed static-dynamic evaluation index system is highly operable in college teaching quality evaluation, and capable of revealing problems in teaching, and clarifying directions for improving teaching quality. The research enriches the theoretical and practical evidence of college teaching quality evaluation, and promotes the teaching quality of economic management majors in colleges from both theoretical and practical angles.
\end{abstract}

Keywords - static evaluation, dynamic evaluation, colleges, economic management majors, teaching quality evaluation

\section{$1 \quad$ Introduction}

China is implementing the college enrollment expansion policy these years, and the number of college graduates is on the rise over the past few years. However, these graduates are facing employment difficulties, while the employer units are dealing with the prominent problem of talent shortage. Such contradiction could be attributed to the gap between the quality of talents cultivated by colleges and the actual social demand [1]. Hence, how could our college education better meet market demand and improve teaching quality is an important topic to be solved by current Chinese colleges and universities. Teaching quality evaluation is a useful tool for testing and ensuring college teaching quality, and a good method for supervising teaching quality improvement, thus, establishing a set of scientific, reasonable, and sound teaching quality evaluation system is a meaningful thing for enhancing college teaching quality. 
By reviewing past references, we found that, foreign studies concerning the evaluation of teaching quality started earlier than China, then with the progress of the times, the ideas and concepts held by scholars have undergone big changes. The earliest form of teaching evaluation is the test on whether students have mastered the content of textbooks [2]. Then, some scholars proposed that the essence of education evaluation is to measure whether the education has achieved the expected educational goals [3], and some scholars argue that the focus of teaching quality evaluation is to find out deficiencies existing in the teaching process, thereby pointing out directions and providing references for educational reform, it shouldn't be limited to the evaluation of final results [4]. Moreover, there're also some scholars that advocate diversified teaching quality evaluation, that is, different evaluators should be invited to give qualitative and quantitative evaluations from multiple angles [5]. After that, more and more countries and scholars began to develop various evaluation index systems and evaluation methods. By the 1980s, the research on the teaching quality management system of economic management majors received great attention from all countries [6]. Dynamic evaluation originated from foreign studies; compared with static evaluation, it emphasizes more on the combination of teaching and evaluation, students' abilities and potentials, and the regulative and promotive roles of teaching quality evaluation [7]. In contrast, domestic studies on teaching quality evaluation are still in a start-up stage, and previous college teaching quality evaluation works are mostly static evaluation, namely the evaluation of teaching results, which only pays attention to students' mastery of knowledge, while ignoring the evaluation on students' ability development and learning potentials [8]. In terms of the application of dynamic evaluation theories, there're very few research results in Chinese college teaching quality evaluation, especially the teaching quality evaluation of economic management majors.

Based on above analysis and findings, this paper took the economic management majors in Chinese colleges and universities as an example, and established a teaching quality evaluation index system for the economic management majors from both the perspectives of static and dynamic evaluations, then, this paper applied the proposed evaluation index system to research the teaching quality of economic management majors in Chinese colleges and universities.

\section{Investigation and analysis of the current state and influencing factors of teaching quality evaluation of economic management majors in Chinese colleges and universities}

Since the implementation of China's national policy of reform and opening-up, the market economic system in China is transforming, and the Chinese socialist market economy has witnessed an unprecedented prosperity. Enterprises of various types and scales have sprung up in response to the proper time and conditions, and their fast development has put forward higher requirements for talents engaging in economic management works in terms of both quantity and quality. To answer the society's call for economic management talents, Chinese colleges have successively set up the eco- 
nomic management majors, however, as the quantity has increased, the quality is unsatisfactory [9]. As mentioned in above paragraph, teaching quality evaluation is an important means to ensure college teaching quality, therefore, this paper took $10 \mathrm{Chi}$ nese colleges in a province that have set up the economic management majors as subjects, and combined questionnaire survey and interviews to investigate and analyze the current state and influencing factors of the teaching quality evaluation of economic management majors in these schools.

\subsection{Characteristics of economic management majors}

Economic management majors are disciplines involving multiple research fields such as economics, management, psychology, and statistics. The learning content of these majors is a set of theories summarized by experts, scholars, and managers during actual economic management activities. Economic management majors are very practical disciplines, and they are closely related to actual economic management activities in the industry, therefore, students of these majors should possess not only relevant theoretical knowledge, but also a comprehensive literacy of multiple disciplines; and the schools, educators, and teachers must make efforts to cultivate their students in these aspects, so that in the workplace, the students can well handle the interpersonal relationship, and have the abilities to discover, analyze, and solve problems according to actual conditions [10].

\subsection{Current state and influencing factors of the teaching quality evaluation of economic management majors in colleges and universities}

Existing college teaching quality evaluation mainly includes three types: evaluation by third-party institutions, evaluation by the Ministry of Education, and the internal evaluation in colleges. For the three types of evaluation, although their emphases are different, their ultimate goal is the same: improving the college teaching quality [11]. This paper mainly aims at the internal teaching quality evaluation in Chinese colleges and universities.

Analysis of teacher questionnaire results. Figure 1 shows the survey results of "Do you think teaching quality evaluation can really improve the teaching quality of economic management majors?" As can be seen from the figure, $35 \%$ of the respondent teachers believe that the implementation of teaching quality evaluation can indeed improve the teaching quality of economic management majors; $50 \%$ of them think the effect is just average, and $15 \%$ of them hold that the effect is little or there's no effect at all.

Figure 2 shows the survey results of "What do you think are the reasons affecting the effectiveness of teaching quality evaluation in colleges?" According to statistics, $90 \%$ of the respondent teachers believe that the unreasonable evaluation indexes are the main reason affecting the effectiveness of teaching quality evaluation; followed by the weights of evaluation indexes. Through further interviews, we found that most teachers think that the current teaching quality evaluation emphasizes too much on the final results (especially the amount of scientific research and teaching tasks), while 
insufficient attention has been paid to the quality evaluation of teaching process. In order to complete the evaluation tasks, teachers have to spend most of their energy on completing the assessment of relevant works and tasks, there's few time and energy left for them to teach and communicate with students.

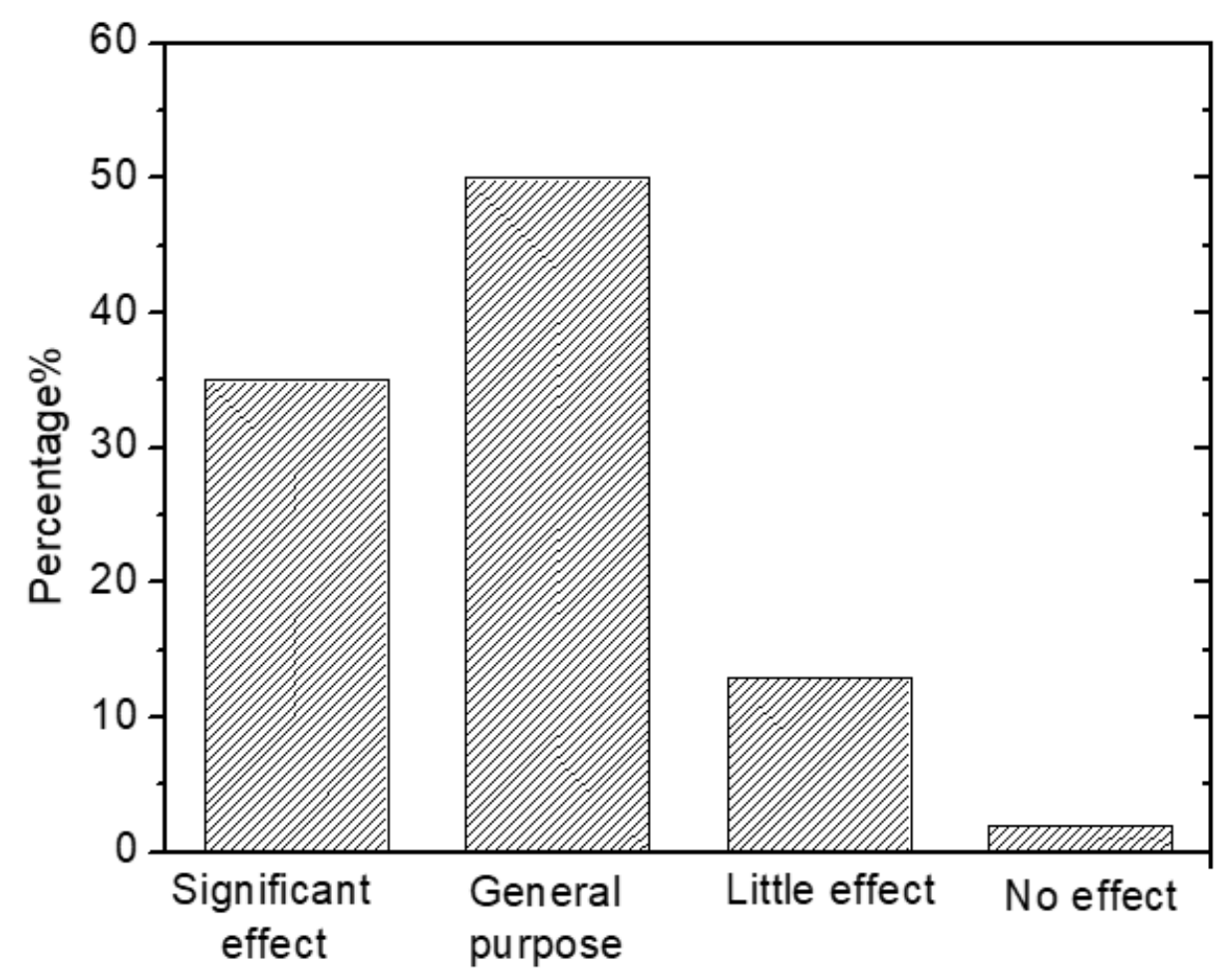

Fig. 1. Statistics on whether the respondents think teaching quality evaluation can really improve the teaching quality of economic management majors 


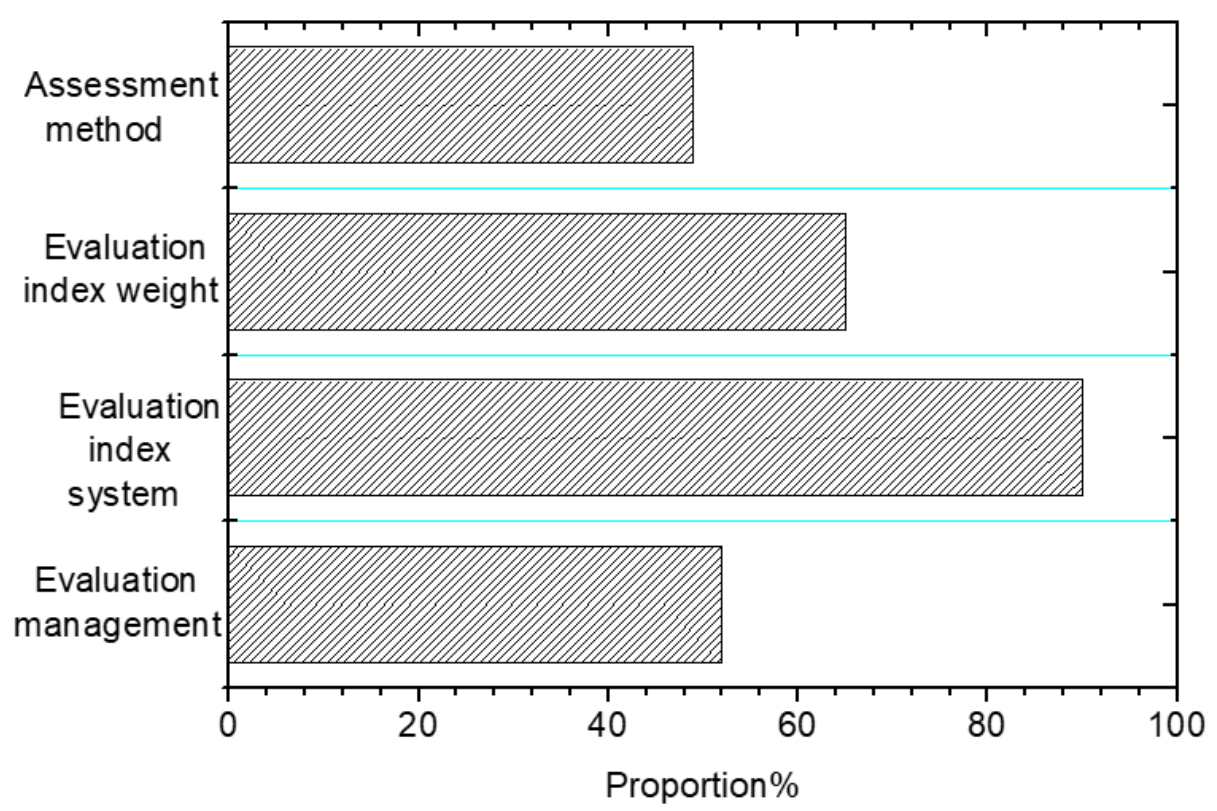

Fig. 2. Statistics on the reasons affecting the effectiveness of teaching quality evaluation in colleges

Figure 3 shows the survey results of "What do you think are the influencing factors of the teaching quality of economic management majors?" As can be read from the data in the figure, most respondent teachers consider the teacher's teaching ability and research ability are the top two influencing factors, followed by the faculty construction situations. 


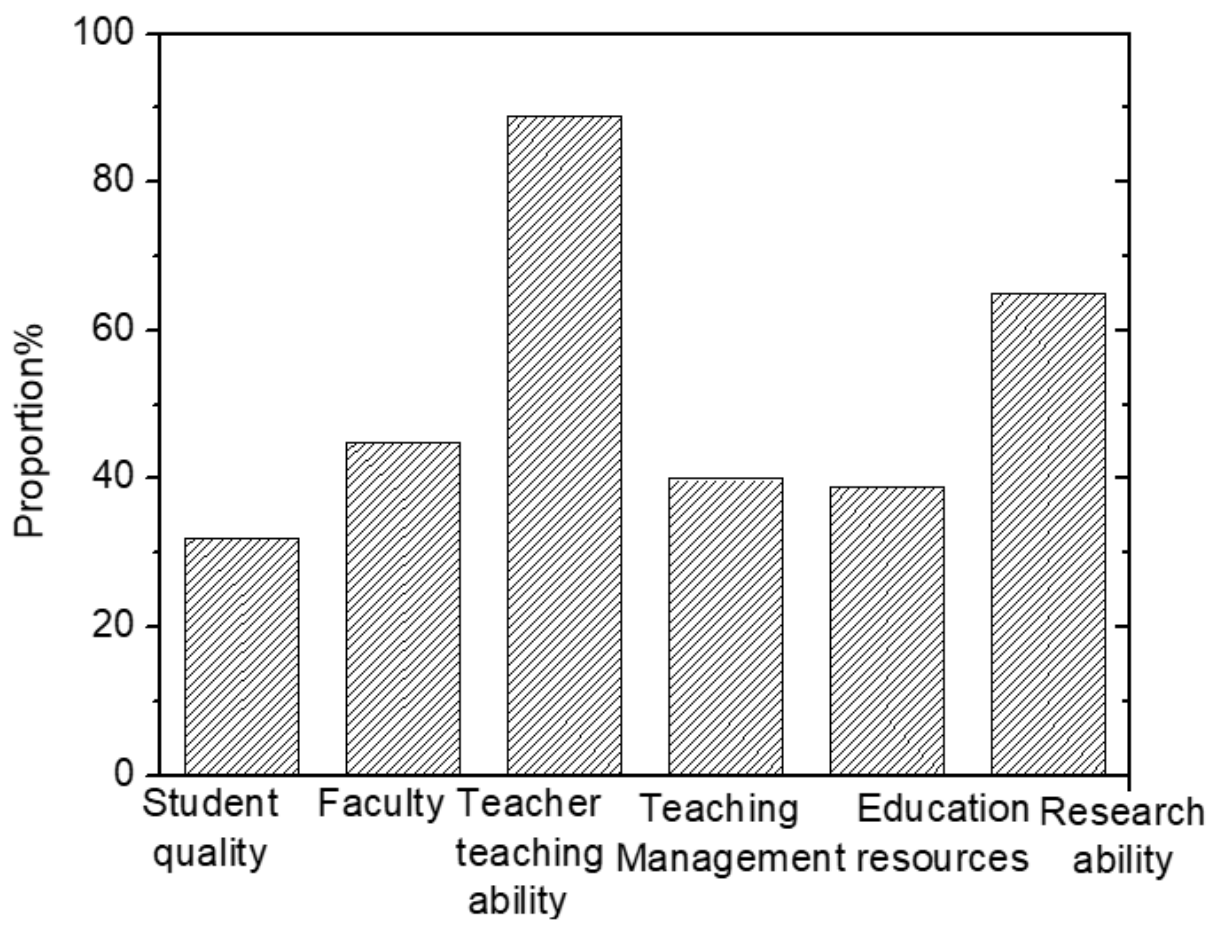

Fig. 3. Statistics on the influencing factors of the teaching quality of economic management majors

Analysis of student questionnaire results. Figure 4 shows the survey results of "What do you think of the teaching quality of your major?" According to the results shown in the figure, most respondent students think that the teaching quality of their economic management majors is average or good; only $9 \%$ of them think the teaching quality is very good, and $13 \%$ of them think the teaching quality is not good or bad. Further interviews revealed that, most students think their teachers just repeat what the textbook says during the teaching process, which is out of touch with the times and reality; some students told us that their teachers adopt the one-way lecturing method in their class, they seldom communicate or discuss with students, the assessment of students is mainly based on the scores of written exams in each semester end, and less emphasis has been paid on students' daily performance and ability development. 


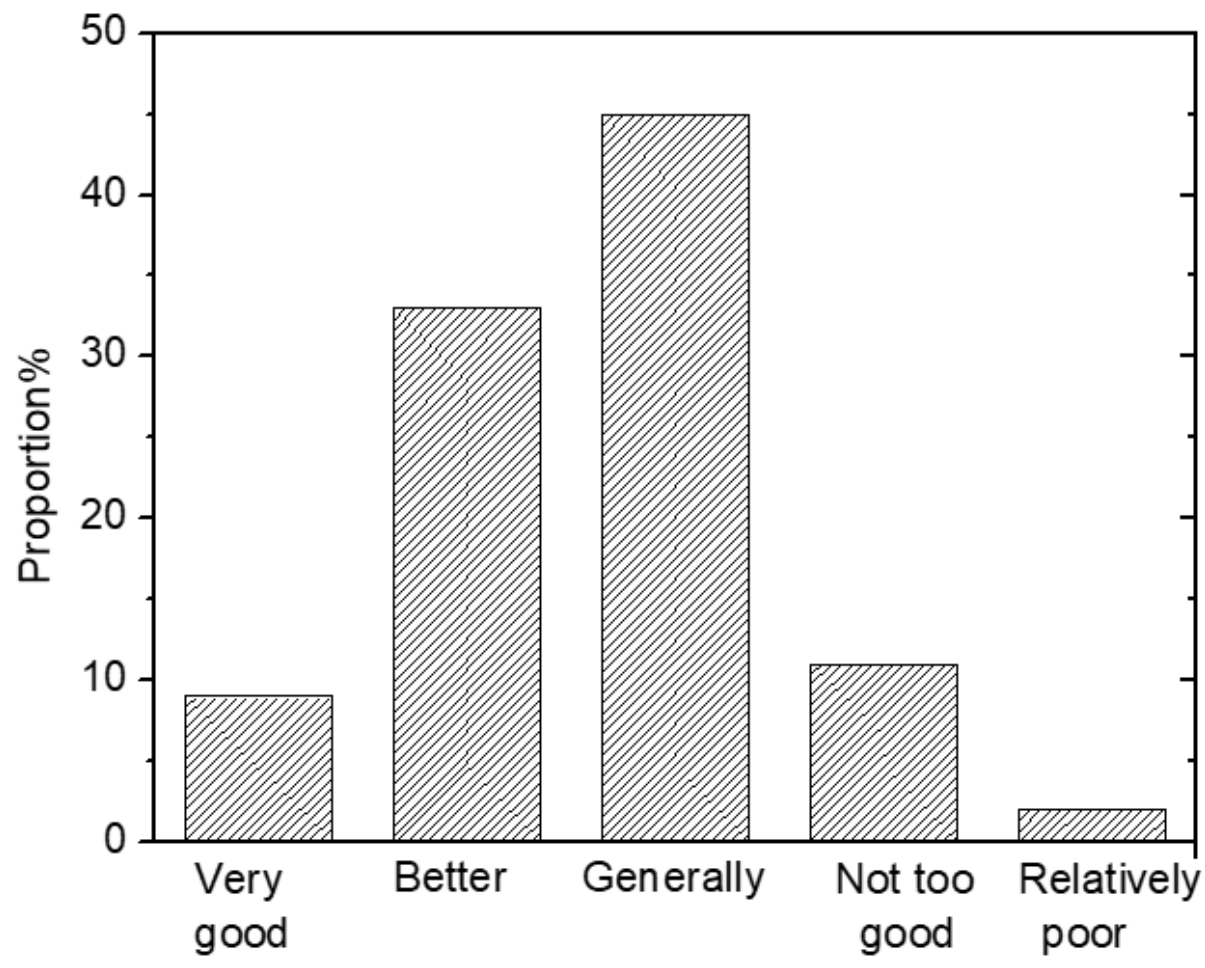

Fig. 4. Statistics on the teaching quality of respondents' majors

Figure 5 shows the survey results of "What do you think are the main influencing factors of the teaching quality of economic management majors?" Statistics suggest that, most respondent students consider the teacher's teaching ability, the teaching evaluation method, and the teaching method are the three main influencing factors. 


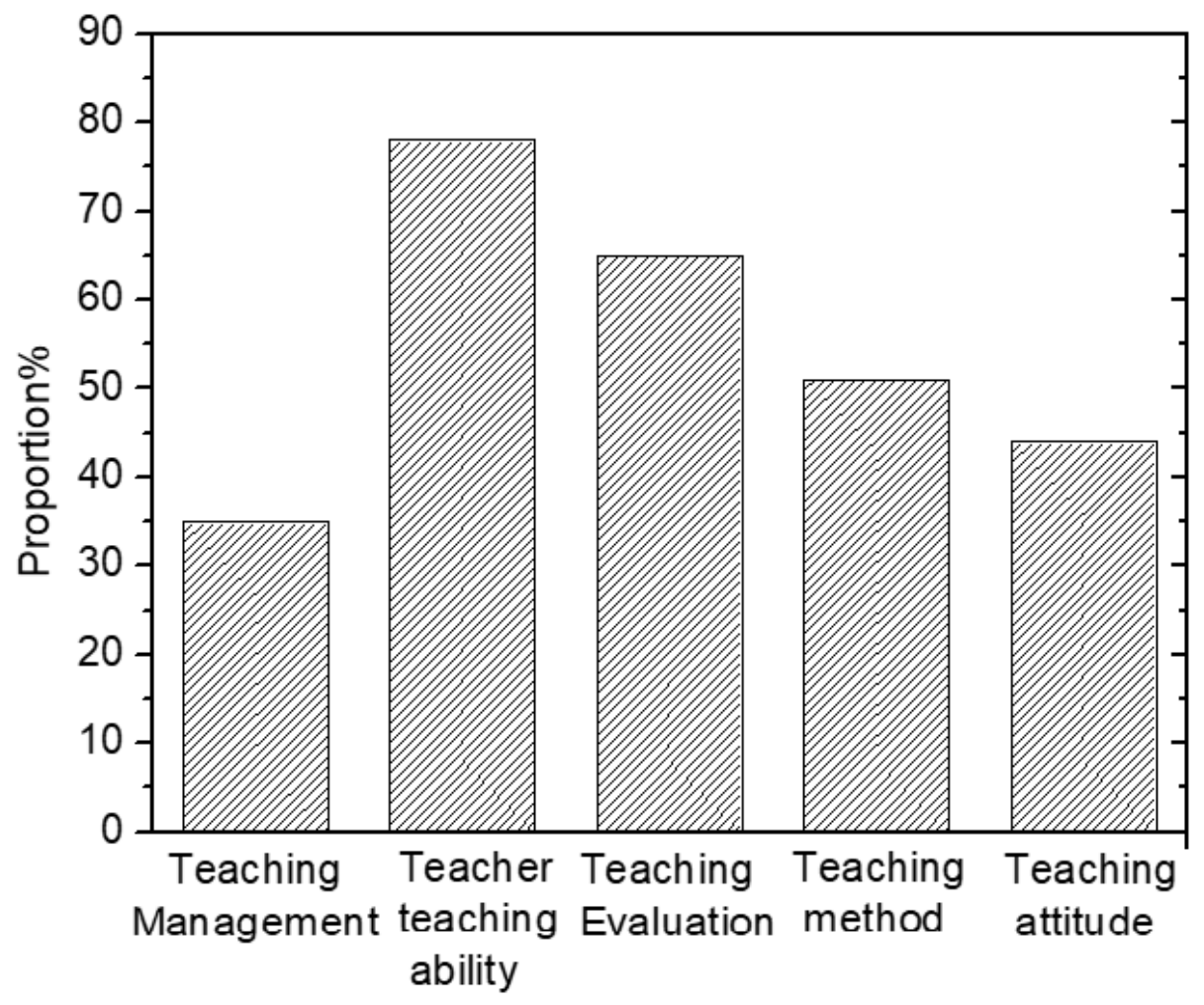

Fig. 5. Statistics on the main influencing factors of the teaching quality of economic management majors

Problems in teaching quality evaluation of economic management majors. After the questionnaire survey conducted in the 10 selected colleges, we had carefully sorted out and analyzed the results of the paper questionnaires and the interviews, and summarized that there're a few problems existing in the teaching quality evaluation of economic management majors in current Chinese colleges, including the unreasonably set evaluation index systems, the overemphasis on static evaluation indexes such as the teacher's scientific research ability and management ability, and the fact that dynamic evaluation indexes that have important impact on teaching quality such as teaching process, method, and attitude have been overlooked. As a result, the teaching quality evaluation has become merely a tool for examining the teaching results, and failed to give feedback of teaching quality, or to stimulate or enhance the teaching quality. 


\section{Teaching quality evaluation of economic management majors in colleges based on static and dynamic evaluations}

\subsection{Construction of the evaluation index system}

Based on the survey results and relevant research results on college teaching quality evaluation, this paper applied the dynamic evaluation theory to the teaching quality evaluation of economic management majors, and designed an evaluation index system based on static and dynamic evaluations, as shown in Table 1, the proposed evaluation index system consists of two first-level indexes: static evaluation index $U_{l}$, and dynamic evaluation index $U_{2}$ [12].

Under the static evaluation index, there're 3 second-level indexes and 12 thirdlevel indexes, the static evaluation index was set to give quantitative teaching evaluation according to traditional evaluation ideas, such as the employment rate of students, the number of excellent graduation thesis, and quantity and quality of scientific research projects, etc. [13].

Under the dynamic evaluation index, there're 4 second-level indexes and 15 thirdlevel indexes. The dynamic evaluation index was set to evaluate the quality of the teaching process, such as the teacher's teaching attitude, teaching content, teaching method, the student's learning enthusiasm, and ability and quality improvement, etc. [14].

The evaluation from both static and dynamic angles can reflect the teaching quality of economic management majors more comprehensively, especially, the evaluation results of dynamic evaluation index are very conducive to providing evidences and pointing out directions for the improvement of teaching quality [15].

Table 1. Evaluation index system of teaching quality of economic management majors

\begin{tabular}{|c|c|c|c|c|c|}
\hline $\begin{array}{l}\text { First-level } \\
\text { index }\end{array}$ & Weight & Second-level index & Weight & Third-level index & Weight \\
\hline \multirow{9}{*}{$\begin{array}{l}\text { Static evalua- } \\
\text { tion index } \\
\qquad\left(\mathrm{U}_{1}\right)\end{array}$} & \multirow{9}{*}{0.4} & \multirow{5}{*}{$\begin{array}{l}\text { Talent development } \\
\qquad\left(\mathrm{U}_{11}\right)\end{array}$} & \multirow{5}{*}{0.41} & $\begin{array}{l}\text { Subject examination passing rate } \\
\qquad\left(\mathrm{U}_{111}\right)\end{array}$ & 0.17 \\
\hline & & & & $\begin{array}{l}\text { Number of outstanding graduation } \\
\text { thesis at school, provincial and na- } \\
\text { tional levels }\left(\mathrm{U}_{112}\right)\end{array}$ & 0.15 \\
\hline & & & & $\begin{array}{l}\text { Number of high-level scholarships } \\
\qquad\left(\mathrm{U}_{113}\right)\end{array}$ & 0.24 \\
\hline & & & & Employment rate $\left(\mathrm{U}_{114}\right)$ & 0.32 \\
\hline & & & & $\begin{array}{l}\text { Progression rate of graduate students } \\
\text { and doctoral students }\left(\mathrm{U}_{115}\right)\end{array}$ & 0.12 \\
\hline & & \multirow{4}{*}{$\begin{array}{l}\text { Scientific research } \\
\text { results } \\
\left(\mathrm{U}_{12}\right)\end{array}$} & \multirow{4}{*}{0.28} & Total number of items $\left(\mathrm{U}_{121}\right)$ & 0.21 \\
\hline & & & & $\begin{array}{c}\text { Number of national and provincial } \\
\text { key projects }\left(\mathrm{U}_{122}\right)\end{array}$ & 0.28 \\
\hline & & & & $\begin{array}{c}\text { Number of papers and monographs } \\
\left(\mathrm{U}_{123}\right)\end{array}$ & 0.19 \\
\hline & & & & $\begin{array}{l}\text { The quality of the thesis and mono- } \\
\text { graph }\left(\mathrm{U}_{124}\right)\end{array}$ & 0.32 \\
\hline
\end{tabular}




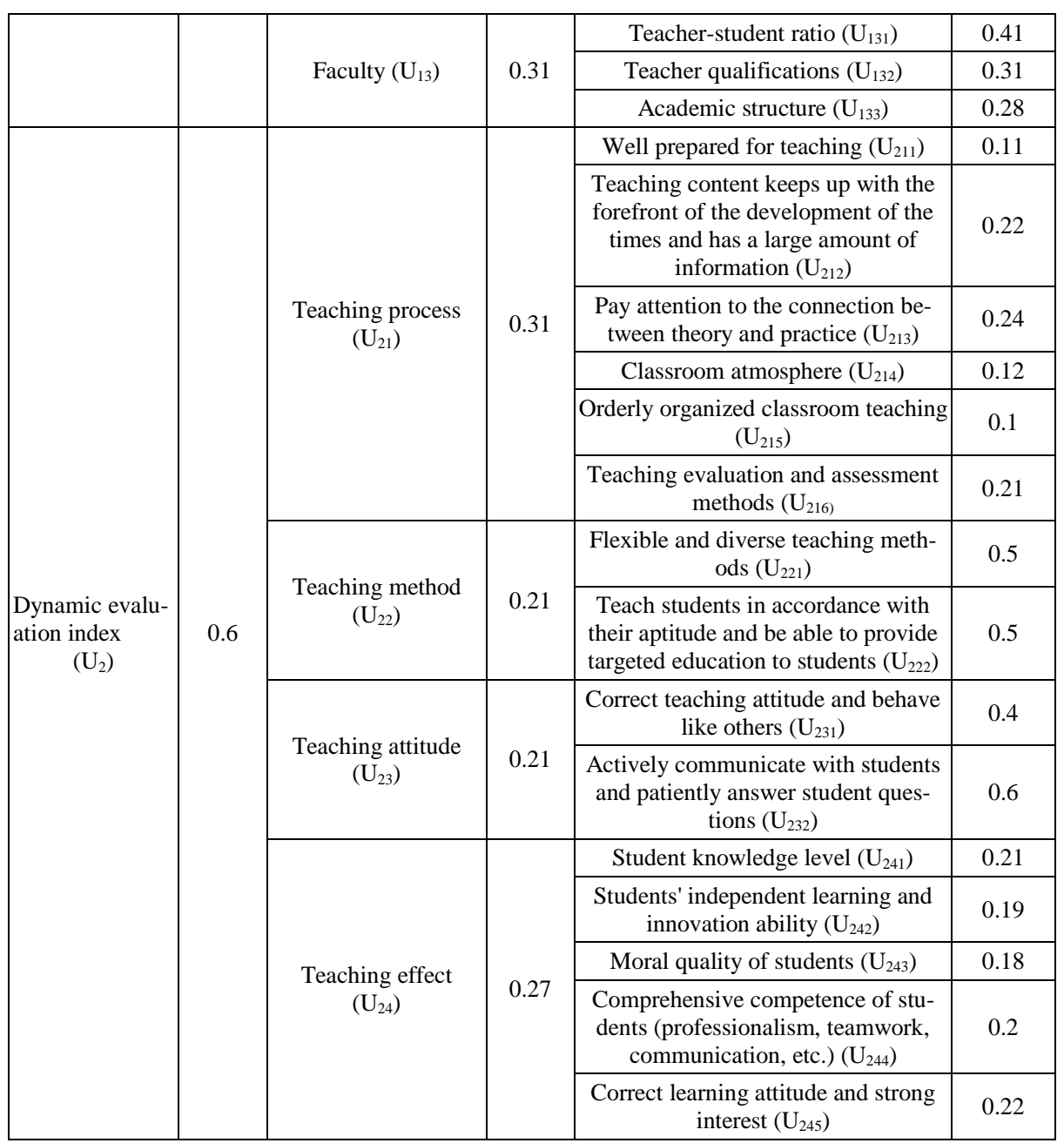

\subsection{Weight values of evaluation indexes}

The assigned weight values of evaluation indexes can greatly affect the evaluation results of college teaching quality; weight can reflect the importance degree of an index to the teaching quality, and whether it can meet the basic requirement of teaching quality or not [16]. Therefore, only when the designed evaluation index weights are in line with the actual situation of economic management majors, can the teaching quality evaluation truly exert its role in promoting the teaching quality of economic management majors. In order to obtain more reasonable weight values, our research team invited 15 experts to anonymously score the designed indexes at each level in the 0-1 scale, the experts included professors engaged in economic management majors, teaching administrators, teachers, and experts who are familiar with teaching 
quality evaluation [17]. After that, the scoring results of experts were summarized to obtain the weight of each index, as listed in Table 1.

\subsection{An empirical research using the proposed evaluation index system}

Before teaching quality evaluation, our research team explained to the participants that the purpose of this evaluation was not to distinguish good and bad teachers and students, the evaluation results wouldn't be taken as references for the performance assessment of teachers and students in the economic management majors, the aim of the empirical research was to diagnose problems existing in the teaching process, find out the specific reasons, and then make corrections to improve the teaching quality in the future. A few things that should be noted are: in order to realize the diagnostic function of teaching quality evaluation, static evaluation should be conducted once a year, while the cycle of dynamic evaluation should be shorter, at least once every semester.

In this paper, the economic management major of a Chinese college was taken as the subject, and the proposed evaluation index system was applied to evaluate the teaching quality of the subject based on static and dynamic evaluations. For teacher respondents, 50 teacher questionnaires were sent out and 48 effective questionnaires were returned; for student respondents, 130 student questionnaires were sent out and 122 effective questionnaires were returned. In the questionnaire, the scores were divided into several levels: excellent (90-100 points), good (80-90 points), average (7080 points), and pass (60-70 points). Respondents only needed to give check marks $(\sqrt{ })$ under the corresponding column. In terms of static evaluation index, and data could be obtained based on professional statistics, then scores were given according to relevant evaluation standards, as for the dynamic evaluation index, the scores were given by both the teachers and students. In this paper, the dynamic evaluation indexes were taken as the example to analyze the process of teaching quality evaluation.

Table 2 gives the statistics of the scores of dynamic evaluation indexes summarized from teacher and student questionnaires, during calculation, the middle value of each evaluation level was taken as the calculation standard.

Table 2. Statistics of evaluation scores

\begin{tabular}{|c|c|c|c|c|c|c|c|}
\hline \multicolumn{3}{|c|}{ Index and weight } & \multicolumn{4}{|c|}{ Evaluation level and percentage } & \multirow[b]{2}{*}{ Score } \\
\hline $\begin{array}{l}\text { First-level } \\
\text { index and } \\
\text { weight }\end{array}$ & $\begin{array}{l}\text { Secondary index } \\
\text { and weight }\end{array}$ & Three-level index and weight & $\begin{array}{l}\text { Excellent } \\
(95)\end{array}$ & $\begin{array}{c}\text { Good } \\
(85)\end{array}$ & $\begin{array}{l}\text { Average } \\
(75)\end{array}$ & $\begin{array}{c}\text { Pass } \\
(65)\end{array}$ & \\
\hline \multirow{3}{*}{$\begin{array}{l}\text { Dynamic } \\
\text { evaluation } \\
\text { index } \\
\left(\mathrm{U}_{2}\right)(0.6)\end{array}$} & \multirow{3}{*}{$\begin{array}{l}\text { Teaching process } \\
\left(\mathrm{U}_{21}\right)(0.31)\end{array}$} & $\begin{array}{l}\text { Well prepared for teaching } \\
\left(\mathrm{U}_{211}\right)(0.11)\end{array}$ & $6 \%$ & $42 \%$ & $50 \%$ & $2 \%$ & 80.2 \\
\hline & & $\begin{array}{c}\text { Teaching content keeps up with } \\
\text { the forefront of the develop- } \\
\text { ment of the times and has a } \\
\text { large amount of information } \\
\left(\mathrm{U}_{212}\right)(0.22)\end{array}$ & $3 \%$ & $30 \%$ & $59 \%$ & $8 \%$ & 77.8 \\
\hline & & $\begin{array}{c}\text { Pay attention to the connection } \\
\text { between theory and practice }\end{array}$ & $4 \%$ & $28 \%$ & $61 \%$ & $7 \%$ & 77.9 \\
\hline
\end{tabular}




\begin{tabular}{|c|c|c|c|c|c|c|}
\hline & $\left(\mathrm{U}_{213}\right)(0.24)$ & & & & & \\
\hline & $\begin{array}{c}\text { Classroom atmosphere }\left(\mathrm{U}_{214}\right) \\
(0.12)\end{array}$ & $2 \%$ & $17 \%$ & $63 \%$ & $18 \%$ & 75.3 \\
\hline & $\begin{array}{c}\text { Orderly organized classroom } \\
\text { teaching } \\
\left(\mathrm{U}_{215}\right)(0.1)\end{array}$ & $12 \%$ & $32 \%$ & $51 \%$ & $5 \%$ & 80.1 \\
\hline & $\begin{array}{c}\text { Teaching evaluation and as- } \\
\text { sessment methods } \\
\left(\mathrm{U}_{216}\right)(0.21)\end{array}$ & $18 \%$ & $36 \%$ & $43 \%$ & $3 \%$ & 81.9 \\
\hline \multirow[b]{2}{*}{$\begin{array}{l}\text { Teaching method } \\
\left(\mathrm{U}_{22}\right)(0.21)\end{array}$} & $\begin{array}{c}\text { Flexible and diverse teaching } \\
\text { methods } \\
\left(\mathrm{U}_{221}\right)(0.5)\end{array}$ & $8 \%$ & $36 \%$ & $45 \%$ & $11 \%$ & 79.1 \\
\hline & $\begin{array}{c}\text { Teach students in accordance } \\
\text { with their aptitude and be able } \\
\text { to provide targeted education to } \\
\text { students } \\
\left(\mathrm{U}_{222}\right)(0.5)\end{array}$ & $2 \%$ & $25 \%$ & $50 \%$ & $23 \%$ & 75.6 \\
\hline \multirow{2}{*}{$\begin{array}{c}\text { Teaching attitude } \\
\left(\mathrm{U}_{23}\right) \\
(0.21)\end{array}$} & $\begin{array}{c}\text { Correct teaching attitude and } \\
\text { behave like others } \\
\left(\mathrm{U}_{231}\right)(0.4)\end{array}$ & $48 \%$ & $42 \%$ & $9 \%$ & $3 \%$ & 90 \\
\hline & $\begin{array}{l}\text { Actively communicate with } \\
\text { students and patiently answer } \\
\text { student questions }\left(\mathrm{U}_{232}\right)(0.6)\end{array}$ & $5 \%$ & $29 \%$ & $43 \%$ & $23 \%$ & 76.6 \\
\hline \multirow{5}{*}{$\begin{array}{l}\text { Teaching effect } \\
\qquad\left(\mathrm{U}_{24}\right) \\
(0.27)\end{array}$} & $\begin{array}{c}\text { Student knowledge level } \\
\left(\mathrm{U}_{241}\right)(0.21)\end{array}$ & $10 \%$ & $46 \%$ & $32 \%$ & $12 \%$ & 80.4 \\
\hline & $\begin{array}{c}\text { Students' independent learning } \\
\text { and innovation ability } \\
\left(\mathrm{U}_{242}\right)(0.21)\end{array}$ & $10 \%$ & $24 \%$ & $36 \%$ & $30 \%$ & 76.4 \\
\hline & $\begin{array}{c}\text { Moral quality of students }\left(\mathrm{U}_{243}\right) \\
(0.18) \\
\end{array}$ & $27 \%$ & $46 \%$ & $15 \%$ & $12 \%$ & 83.8 \\
\hline & $\begin{array}{c}\text { Comprehensive competence of } \\
\text { students (professionalism, } \\
\text { teamwork, communication, } \\
\text { etc.) } \\
\left(\mathrm{U}_{244}\right)(0.2) \\
\end{array}$ & $15 \%$ & $21 \%$ & $55 \%$ & $9 \%$ & 79.2 \\
\hline & $\begin{array}{l}\text { Correct learning attitude and } \\
\text { strong interest }\left(\mathrm{U}_{245}\right)(0.22)\end{array}$ & $12 \%$ & $33 \%$ & $45 \%$ & $10 \%$ & 79.7 \\
\hline
\end{tabular}

After calculation, the total score of the dynamic evaluation index was obtained to be 79.47 points, and the evaluation result was average level. Among the various subindexes, the score of $U_{21}$ was 78.88 points, the score of $U_{22}$ was 77.35 points, the score of $U_{23}$ was 81.96 points, and the score of $U_{24}$ was 79.86 points. After further calculation, the total score of the static evaluation index was 85.65 points, the evaluation result was good level, the comprehensive score of teaching quality was $85.65 \times 0.4+79.47 \times 0.6=81.94$ points, and the evaluation result was that the teaching quality was in a good level. From the table, we can see that, the score of $U_{231}$ was 90 points, indicating an excellent level; the scores of indexes $U_{211}, U_{215}, U_{216}, U_{241}$, and $\mathrm{U}_{243}$ were all between 80-90 points, indicating a good level; and the scores of the rest indexes were between $70-80$ points, indicating an average level. These results show that, overall, the teaching quality of the subject was good, but still, there're shortcom- 
ings to be improved, such as that the it'll be better if the teachers could teach students in accordance with their aptitude, actively communicate with students in a targeted manner, and be more patient when answering students' questions, etc.

\section{Conclusions}

For current Chinese colleges and universities, teaching quality improvement is the key content of their work, and teaching quality evaluation provides a guarantee for this work. In view of this matter, this paper took the economic management majors as an example and studied the college teaching quality evaluation based on static and dynamic evaluations. The specific conclusions are:

1. Combining questionnaire survey and interviews, this study investigated the current state and influencing factors of the teaching quality evaluation of economic management majors in Chinese colleges and universities, and the research findings revealed a few problems, including the unreasonably set evaluation index systems, the overemphasis on static evaluation indexes such as the teacher's scientific research ability and management ability, and the fact that dynamic evaluation indexes that have important impact on teaching quality such as teaching process, method, and attitude have been overlooked.

2. Based on obtained survey results, an evaluation index system was established for college teaching quality based on static and dynamic evaluations, and the weight values of indexes at each level were determined by the expert scoring method.

3. The economic management major in a Chinese college was taken as the subject to conduct an empirical research on its teaching quality evaluation, and the research results prove that the proposed evaluation index system was highly operable and can well reflect the problems existing in the teaching process, which can point out directions for teaching quality improvement in the future.

\section{$5 \quad$ References}

[1] Lin, M. (2020). Evaluation Model and Enhancement Strategies for Teaching Reform Capacity of Art Courses in Higher Vocational Colleges, International Journal of Emerging Technologies in Learning, 15 (8): 124-138.

[2] Bornmann, L., Mittag, S., Danie, H.D. (2006). Quality assurance in higher education - meta-evaluation of multi-stage evaluation procedures in Germany. Higher Education, 52 (4): 687-709. https://doi.org/10.1007/s10734-004-8306-0

[3] Baek, S.G., Kim, K.J. (2003). The effect of dynamic assessment based instruction on children's learning. Asia Pacific Education Review, 4 (2): 189-198. https://doi.org/10.1007/ bf03025361

[4] Han, K. (2020). Evaluation of Teaching Quality of College Physical Education Based on Analytic Hierarchy Process, International Journal of Emerging Technologies in Learning, 15 (10): 86-99. https://doi.org/10.3991/ijet.v15i10.14039

[5] Davies, M., Hirschberg, J., Lye, J., Johnston, C. (2010). A systematic analysis of quality of teaching surveys. Assessment \& Evaluation in Higher Education, 35 (1): 83-96. https://doi. org/10.1080/02602930802565362 
[6] Bai, X., Li, J. (2021). Personalized dynamic evaluation technology of online education quality management based on artificial intelligence big data. Journal of Intelligent and Fuzzy Systems, (Preprint). https://doi.org/10.3233/iifs-219128

[7] Xie, Z., Su, Z. (2021). Evaluation of college English classroom teaching quality dependent on triangular fuzzy number. International Journal of Electrical Engineering Education, 002072092110020. https://doi.org/10.1177/00207209211002075

[8] Sun, Q. (2021). Evaluation model of classroom teaching quality based on improved RVM algorithm and knowledge recommendation. Journal of Intelligent and Fuzzy Systems, 40(2): 2457-2467. https://doi.org/10.3233/jifs-189240

[9] Wang, T.H. (2010). Web-based dynamic assessment: taking assessment as teaching and learning strategy for improving students' e-learning effectiveness. Computers \& Education, 54 (4): 1157-1166. https://doi.org/10.1016/j.compedu.2009.11.001

[10] Poehner, M.E., Lantolf, J.P. (2005). Dynamic assessment in the language classroom. Language Teaching Research, 9 (3): 233-265. https://doi.org/10.1191/13621688051r166oa

[11] Zhang, C., Liu, F., Jing, W. (2010). Set pair mathematical model of teaching quality evaluation system and its application. 3rd International Conference on Human System Interaction, Rzeszow, Poland, pp. 531-535. https://doi.org/10.1109/hsi.2010.5514516

[12] Sizer, J. (1994). Teaching quality assessment in higher education institutions in Scotland: The staff development aspects of Scottish higher education funding council quality assessment framework. Higher Education Policy, 7 (2): 50-51. https://doi.org/10.1057/hep. $\underline{1994.25}$

[13] Stevens, R.J. (1978). Discrepancies in Student Evaluation of University Teaching Quality. American Biology Teacher, 40 (9): 534-540. https://doi.org/10.2307/4446409

[14] Laughton, D. (2003). Why was the QAA approach to teaching quality assessment rejected by academics in UK HE? Assessment \& Evaluation in Higher Education, 28(3): 309-321. https://doi.org/10.1080/0260293032000059658

[15] Elliott, M., Kaufman, S., Gardner, R., Burgess, G. (2002). Teaching conflict assessment and frame analysis through interactive web-based simulations. International Journal of Conflict Management, 13(4): 320-340. https://doi.org/10.1108/eb022880

[16] Muskett, T., Body, R., Perkins, M. (2012). Uncovering the dynamic in static assessment interaction. Child Language Teaching \& Therapy, 28 (1): 87-99. https://doi.org/10.1177/ 0265659011428966

[17] Delandshere, G. (1996). From static and prescribed to dynamic and principled assessment of teaching. The Elementary School Journal, 97 (2): 105-120. https://doi.org/10.1086/ $\underline{461857}$

\section{Authors}

Jianli Liu, received his Master's degree in engineering from University of Electronic Science and Technology of China. He has been teaching in Shijiazhuang University of Applied Technology since 2002. His main research area is business administration.

Yuan Wang, graduated from Hebei University of Architecture. She has been teaching in Shijiazhuang University of Applied Technology since 2006. Her main research areas are construction electrical, project management and project cost (Email: wangyuan@sjzpt.edu.cn).

Article submitted 2021-10-23. Resubmitted 2021-12-07. Final acceptance 2021-12-18. Final version published as submitted by the authors. 